\title{
Late Pleistocene sedimentation in the Northern Caspian Lowland during the Early Khvalynian transgression
}

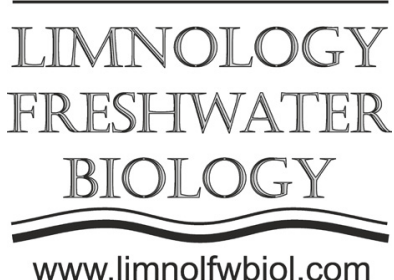

\author{
Makshaev R.R.*, Svitoch A.A., Tkach N.T. \\ Lomonosov Moscow State University, Leninskie Gory-1, 119991, Moscow, Russia
}

\begin{abstract}
Early Khvalynian basin was one of the largest in the history of the Caspian Sea during the Pleistocene. Six lithofacies ( $L F 1-L F 6)$ with two subfacies $(L F 2 a-L F 2 b)$ are recognized in lower khvalynian deposits in the Lower Volga Region (the Northern Caspian Lowland). The chocolate clay deposition in the Lower Volga region corresponds to an interval between 16.4-12.7 cal ka BP. According to radiocarbon dates, the age of the Early Khvalynian stage in the Lower Volga Region is varying between 20-12.6 cal ka BP. The most density of the radiocarbon dates is between 14.1-13.5 ka ago. The interval between 14.5-14.1 ka ago is characterized by the absence of mollusc shells and deposition of massive chocolate clay. Comparison radiocarbon data of mollusc shells and lithofacies characteristics of khvalynian sediments reveal a certain pattern with the main late Pleistocene climatic events and allow us to reconstruct the depositional history during LGM to Younger Dryas at the Lower Volga Region.
\end{abstract}

Keywords: Caspian Sea, Late Pleistocene, chocolate clay, lithofacies, radiocarbon dating

\section{Introduction}

During the late stage of the late Pleistocene, one of the largest transgression (Early Khvalynian) in the history of the Caspian Sea occurred (Svitoch, 2014). Development of the Early Khvalynian basin during late Pleistocene was influenced by transformation and afterward degradation of the Late Valdai Ice Sheet and large permafrost area in the north-west part of the Russian Plain (Kvasov, 1975, Yanina et al., 2018). During the Early Khvalynian epoch on the north-west of the Early Khvalynian basin, a unique lithofacies (chocolate clay) were deposited. Despite large materials about paleogeography of the Early Khvalynian epoch in the Northern Caspian Lowland, is still a lack of data about stages of lower khvalynian deposition and their connection with climatic fluctuation during the late Pleistocene.

\section{Material and methods}

During the fieldwork (2011-2017), lower khvalynian deposits in the Volga River and Akhtuba River outcrops were studied. Khvalynian malacofauna was identified, measured, and compared with sedimentological features. The lithofacies analysis is based on Nichols (2009). We also analyzed 61 radiocarbon dates of khvalynian mollusc shells collected from many sections and sites in the Lower Volga Region (Yanina et al., 2018).

\section{Results and discussions}

Six lithofacies (LF1-LF6) with two subfacies (LF2a-LF2b) are recognized in the studied sections. Lithofacies LF6 was deposited during the late stage of the last glacial maximum (LGM) and according to four radiocarbon dates are dated at 20-19.1 cal ka BP. The deposition of laminated grey clay and silt with sparse mollusc shells indicate a supply of marine transgression water to the Northern Caspian Lowland. Lithofacies LF5 cross-lamination sand with mollusks shells indicates moderate to high depositional energies associated with estuarine complexes. The appearance of small thinvalved shells of Didacna ebersini in sediments indicates cold, low-brackish (6-7\%) water conditions and initial stage of Early Khvalynian transgression (Yanina, 2012). Three radiocarbon dates indicate 17.9-16.7 cal ka BP. Lithofacies LF4 indicates the deposition of chocolate clay and silt with molluscs shells. Fourteen radiocarbon dates present the interval between 16.4-14.8 cal ka BP. Lithofacies $L F 3$ is located between $L F 2 a$ and $L F 2 b$ and consists of a shelly sand layer with large in-situ brackish water mollusc shells Didacna protracta, D. ebersini, Dreissena polymorpha. Five radiocarbon dates indicate an interval between 14.1-13.8 cal ka BP. This lithofacies is commonly associated with low depositional energies and could be attributed to shallow marine or shoreline complexes. Lithofacies LF2b (massive chocolate clay) indicates deposition from a large amount of suspended fine materials with low to moderate flows in a low-brackish palaeoestuarine and lagoon settings 
(Baduykova, 2010). Mollusc shells were radiocarbon dated at 14.7-14.4 cal ka BP. No radiocarbon dates were obtained between 14.4-14.1 cal ka BP. Lithofacies $L F 2 a$ is characterized by the deposition of chocolate clay with thin silt and sand layers with mollusc shells Didacna protracta, Dreissena polymorpha, Monodacna caspia. Twenty four radiocarbon dates indicate the interval between 13.7-12.7 cal ka BP. Deposition lithofacies LF1 consists of brown silt, brown and yellow sand with thin shell detritus which formed Baer knolls formations and corresponds to the Late Khvalynian stage. Three radiocarbon ages were dated at 10.9-8.2 cal ka BP.

\section{Conclusion}

Sedimentological processes in the Lower Volga Region, the north-west of the Northern Caspian Lowland, were affected by the Late Pleistocene climatic fluctuations. The main contribution of supply water and materials to the north-west part of the Early Khvalynian basin depended on the Volga River discharge. The development of the Early Khvalynian basin in the Lower Volga region corresponds to the interval between 2012.7 cal ka BP. Despite the large extent of studied area (app. $300 \mathrm{~km}$ ) lithofacies LF2a, LF2b, LF3 and LF4 are identified, which suggests similar deposition conditions under estuarine, lagoon and shallow marine complexes in the north-west part of the Early Khvalynian basin. At the beginning of the Early Khvalynian transgression on of the Northern Caspian Lowland was characterized by the sedimentation in preKhvalynian paleodepressions, palaeovalley, represented by grey and light-brown clay and silt ( $L F 6)$ deposits and the first appearance of mollucs Didacna protracta.

\section{Acknowledgements}

This research was funded by a grant from the Russian Science Foundation (№ 20-77-00068).

\section{References}

Badyukova, E.N., 2010. Evolution of the Northern Caspian Sea region and the Volga delta in the late PleistoceneHolocene. Oceanology 50 (6): 953-960.

Kvasov, D.D., 1975. Late Quaternary History of the Large Lakes and Inland Seas of the Eastern Europe. Nauka, Leningrad. (in Russian).

Nichols, G. 2009. Sedimentology and Stratigraphy. Wiley-Blackwell, Chichester.

Svitoch A.A., 2014. The Great Caspian Sea: structure and history. Moscow University Press. (in Russian).

Volga Delta. 2018. In: Yanina T.A. (Ed). Lomonosov Moscow State University. (in Russian).

Yanina, T.A., 2012. Neopleistocene of the Ponto-Caspian Region: Biostratigraphy, Paleogeography, Correlation. Lomonosov Moscow State University. (in Russian).

Yanina, T.A., Sorokin, V., Bezrodnykh, Y., Romanyuk, B., 2018. Late Pleistocene climatic events reflected in the Caspian Sea geological history (based on drilling data). Quaternary International. 465:130-141. 